\title{
Search for Mycobacterium leprae in wild mammals
}

\section{ABSTRACT}

Leprosy is still a worldwide public health problem. Brazil and India show the highest prevalence rates of the disease. Natural infection of armadillos Dasypus novemcinctus with Mycobacterium leprae has been reported in some regions of the United States. Identification of bacilli is difficult, particularly due to its inability to grow in vitro. The use of molecular tools represents a fast and sensitive alternative method for diagnosis of mycobacteriosis. In the present study, the diagnostic methods used were bacilloscopy, histopathology, microbiology, and PCR using specific primers for M. leprae repetitive sequences. PCR were performed using genomic DNA extracted from 138 samples of liver, spleen, lymph nodes, and skin of 44 D. novemcinctus, Euphractus sexcinctus, Cabassous unicinctus, and C. tatouay armadillos from the Middle Western region of the state of São Paulo and from the experimental station of Embrapa Pantanal, located in Pantanal da Nhecolândia of Mato Grosso do Sul state. Also, the molecular analysis of 19 samples from internal organs of other road killed species of wild animals, such as Nasua nasua (ring-tailed coati), Procyon cancrivoros (hand-skinned), Cerdocyon thous (dog-pity-bush), Cavia aperea (restless cavy), Didelphis albiventris (skunk), Sphigurrus spinosus (hedgehog), and Gallictis vittata (ferret) showed PCR negative data. None of the 157 analyzed samples had shown natural mycobacterial infection. Only the armadillo inoculated with material collected from untreated multibacillary leprosy patient presented PCR positive and its genomic sequencing revealed $100 \%$ identity with $M$. leprae. According to these preliminary studies, based on the used methodology, it is possible to conclude that wild mammals seem not to play an important role in the epidemiology of leprosy in the Middle Western region of the São Paulo state and in the Pantanal of Mato Grosso do Sul state.

Keywords: Dasypus novemcinctus, Euphractus sexcinctus, Cabassous tatouay, Mycobacterium leprae, eco-epidemiology, wild mammals.

[Braz J Infect Dis 2010;14(1):47-53] @Elsevier Editora Ltda.

\section{INTRODUCTION}

Leprosy, a millenarian illness described in China, India and Egypt at $600 \mathrm{aC},{ }^{1}$ is still considered a serious Public Health problem. M. leprae, the etiological agent, differently from other in vitro cultured Mycobacteria whose ecological niches are very well defined, has still important unknown points in its eco-epidemiology.

Generally, Mycobacteria are microorganisms highly adapted to the environment where they live. Particularly M. leprae, which is a bacillus highly adapted to the human being to whom they rely for its survival and perpetuation.

Inter-human leprosy transmission is known to occur through frequent and constant con- tact with multibacillary patients, the main bacilli shedders. The majority of the healthy individuals, when infected, usually do not develop the disease. ${ }^{2}$ However, based on genetic, nutritional and immunological factors, about $10 \%$ of the population can develop leprosy after frequent and constant contact with high loads of bacilli disseminated by aerial route. The bacilli tend to grow mainly in the extremities of the body, where they survive inside macrophages and infect the Schwann cells of peripheral nervous system. The deficient myelin production in infected Schwann cells and its destruction by immune-mediated reactions cause nerve damage, loss of sensibility, and disfigurement of patients. ${ }^{2}$
Authors

Sílvia Cristina Barboza

Pedrini, $\mathrm{MD}^{1}$

Patrícia Sammarco Rosa, $\mathrm{MD}^{1}$

Ísis Meri Medri, $\mathrm{MD}^{2}$ Guilherme Mourão,MD ${ }^{2}$ Eduardo Bagagli,

Professor ${ }^{3}$

Carlos Alberto de Magalhães Lopes, Professor $^{3}$

${ }^{1}$ Instituto Lauro de Souza Lima, Bauru - São Paulo, Brazil

${ }^{2}$ Embrapa Pantanal -

Corumbá, MS

${ }^{3}$ Microbiology and Immunology Department, Instituto de Biociências,

Universidade Estadual Paulista (UNESP)

Botucatu, São Paulo, Brazil.

Submitted on: 08/03/2009 Approved on: 11/22/2009

Correspondence to:

Sílvia Cristina Barboza Pedrini

Rodovia Comandante João Ribeiro de Barros, km 225/226

PO Box 3021

Bauru, SP, Brasil

CEP: 17034-971

E-mail: silviapedrini@ yahoo.com.br

We declare no conflict of interest. 
Besides failures in isolating M. leprae from the environment, the lack of epidemic outbreaks and the low reproducibility of natural infection cases make it difficult to elucidate the habitat of this organism. The exact source of infection is not known, which seems to reflect an extremely restricted ecological niche of this microorganism.

With the recent progress of molecular biology techniques, some aspects of the biology and ecology of $M$. leprae have been cleared. Molecular markers have been used thoroughly in leprosy diagnosis and research. PCR products can be analyzed by agarose gel electrophoresis or slot-blot hybridization, using specific probes, such as the 212 bp one, which binds to an internal segment of the 360 bp region of $M$. leprae $18 \mathrm{kDa}$ gene. ${ }^{3}$ Analysis of polymorphisms of PCR fragments after enzyme digestion (PRA) for the hsp65 gene, present in all mycobacteria ${ }^{4}$ was used also for the characterization of M. leprae. ${ }^{5}$ Woods and Cole (1989), based their PCR on the specific repetitive element of M. leprae (RLEP) demonstrated by visualization of a 372 bp product. ${ }^{6}$ This marker was later used for DNA hybridization by Santos et al. (1993). ${ }^{7}$ The search for the pathogen in wild and domestic animals is practically unexplored. Except for non-human primates, the unique animal group in which M. leprae grows successfully is in armadillos, especially the nine-banded $D$. novemcinctus. ${ }^{8,9}$

Experimental studies involving armadillos D. novemcinctus show that these animals develop a disseminated form of disease. This animal model is valuable because when inoculated with $M$. leprae, armadillos produce large amounts of bacilli that can be used in the development of diagnostic tests for preparation of Mitsuda antigen and antigens fractions production. ${ }^{10-12}$

Armadillos belong to the Order Cingulata, ${ }^{13}$ which had its evolutionary development centered in South America since the Paleocene era, around 65 million years ago, when the South American continent was already separated from the African continent, but still disconnected from North America. ${ }^{14,15}$ The nine-banded armadillo was introduced in North America about $170^{14,16}$ and indigenous infection in armadillos was observed more recently. ${ }^{17,18}$ Significant progress in $M$. leprae global eco-epidemiology knowledge was also possible after studies of molecular and genomic characterization of several strains coming from different parts of the world. Through single nucleotides polymorphism analysis (SNPs), it was verified that the origin of M. leprae remounts to the African continent, having been disseminated from Africa to Asia and later to Europe. The arrival of the bacillus in America must have occurred recently, about 500 years ago, during the New World colonization. ${ }^{19}$

In the present study, using molecular tools in different species of wild animals and in four species of armadillos $(D$. novemcinctus, Euphractus sexcinctus, Cabassous tatouay and
C. unicinctus), we aimed at searching for M. leprae carriers and discuss the role of these animal hosts in the epidemiology of leprosy in the Middle-west area of São Paulo state, where leprosy is endemic, and also in Pantanal of Mato Grosso do Sul state, where leprosy is still hiperendemic.

\section{MATERIAL AND METHODS}

\section{Animals}

Liver fragment from an $M$. leprae experimentally infected armadillo. As positive control for PCR reaction, a $M$. leprae infected liver fragment was used for DNA extraction. A $D$. novemcinctus armadillo was previously inoculated with $M$. leprae suspension by subcutaneous and intravenous route $\left(10^{8}\right.$ bacilli $\left./ \mathrm{mL}\right)$. This animal was maintained captive for 20 months and evaluated bimonthly until the appearance of disseminated disease. After necropsy the animal showed granulomas in the liver, spleen $\left(3.06 \times 10^{9}\right.$ bacilli/g), lymph nodes, lungs, adrenals glands, and skin. ${ }^{20,21}$

Wild armadillos. A total of 44 wild armadillos of four different species (D. novemcinctus $\mathrm{n}=18$; E. sexcintus $\mathrm{n}=22$; C. tatouay $\mathrm{n}=02$; C. unicinctus $\mathrm{n}=02$ ), young adults, males and females, weights varying from $3.5 \mathrm{~kg}$ to $6.5 \mathrm{~kg}$ were studied. The animals from São Paulo were captured in the Middle Western area of the state of São Paulo, in the municipalities of Botucatu (22nd 56' 15” S, 48th 26' 15” W), Pardinho, São Manuel (23rd 03’ 45” S, 48th. 18', 45” W), Manduri (23rd 03' 45" S, 49th 18'45” W) and Bauru (22nd 18 ' 41" S, 49th 03' 45” W). Besides, we had captured armadillos from the Nhumirim ranch, an experimental station of Embrapa Pantanal, located in the Pantanal da Nhecolândia of the Mato Grosso do Sul state ( $18^{\circ} 59^{\prime}$ S; $56^{\circ}$ $\left.39^{\prime} \mathrm{W}\right)$. From these animals a total of 138 samples were obtained: 26 ear fragments, 32 feces, 21 nostril swab, 20 blood, and 39 internal organs (liver $\mathrm{n}=15$; spleen $\mathrm{n}=7$; lymph nodes $\mathrm{n}=10$; kidney $\mathrm{n}=1$; adrenal glands $\mathrm{n}=1$, and lungs $\mathrm{n}=2$ ).

Other wild animal species. Ten road killed animals were also analyzed (Ring-Tailed Coati Nasua nasua $\mathrm{n}=$ 02; skunk Didelphis albiventris $\mathrm{n}=1$; hedgehog Sphigurrus spinosus $\mathrm{n}=01$; hand-skinned Procyon cancrivoros $\mathrm{n}=01$; restless cavy Cavia aperea $\mathrm{n}=1$; ferrets Gallictis vittata $\mathrm{n}=2$, and dog-pity-bush Cerdocyon thous $\mathrm{n}=2$ ), being a total of 19 samples collected.

Amount of animals. The apparently small sample collection is justified by the Ambient Protection Lays of Brazilian wild animal's biodiversity. So it isn't permitted to use a lot of specimens, according to the Brazilian Institute of Environment and Renewable Natural Resources (IBAMA) and the Ethic Principles Committee.

Euthanasia. Armadillos were previously anesthetized with tiletamine and zolazepam $(5.0 \mathrm{mg} / \mathrm{kg} / \mathrm{I} . \mathrm{M})$ and sub- 
mitted to subclavian vein puncture for the total blood collection. All animals were captured under supervision of the Brazilian Institute of Environment and Renewable Natural Resources (IBAMA), license number 187/05 and 006/2007B.

Necropsy and sampling. From the wild armadillos, samples of blood, nostril swab, liver, spleen, mesenteric lymph nodes, lungs, adrenal glands, kidneys, and ear fragments were collected. DNA samples of feces of armadillo were supplied from the DNA Bank of the Micology Laboratory of the Department of Microbiology and Immunology (Institute of Biosciences, UNESP, Botucatu, SP, Brazil). Fragments of liver, spleen, lymph nodes, and skin were collected also for histopathological examination using the Faraco-Fite staining method.

\section{Microbiological methods}

Organ decontamination and digestion. Organs fragments were weighted and ground in $2,0 \mathrm{~mL}$ of sterile distilled water. Samples were decontaminated by the Petroff Method $^{22}$ and the sediment was used for culture and bacilloscopy.

Semi-quantitative bacilloscopy. Smear of $10 \mu \mathrm{L}$ of the sediment obtained after processing of organ samples were cold stained by Ziehl-Neelsen staining method. One hundred fields of the slides were examined under light microscope (100x magnification). The results were expressed by the semi-quantitative method as for tuberculosis diagnosis and for other mycobacteriosis, according to the following criteria:

- (-) negative for acid fast bacilli (AFB) in $100 \mathrm{ex}-$ amined fields;

- $(+)$ less than a AFB/field in 100 examined fields;

- (++) from 1 to $10 \mathrm{AFB} /$ field in 50 examined fields;

- $(+++)$ more than $10 \mathrm{AFB} /$ field in 20 examined fields.

Culture. Liver, spleen and mesenteric lymph nodes were inoculated in LJ culture medium with $2,5 \%$ ferric citrate in duplicate tubes with tight lids. The tubes were incubated at $37^{\circ} \mathrm{C}$ and observed daily in the first week and then weekly up to 90 days until the appearance of colonies. Cultures were considered negative in the absence of growth.

\section{Molecular methods}

DNA extraction. After criofracture, the organ samples (about $300 \mathrm{mg}$ ) were submitted to a pre-treatment, ${ }^{23,24}$ before digestion with Proteinase-K. Thus, after maceration with liquid nitrogen (N2 liq), the material was transferred to $1.5 \mathrm{~mL}$ micro tube with $600 \mu \mathrm{L}$ of Tris$\mathrm{HCl}$ 10mM; EDTA 1mM; pH8,0 (TE). Samples were homogenized in vortex and centrifuged at 14,000 rpm/ $25^{\circ} \mathrm{C} / 5 \mathrm{~min}$. The supernatants were discarded and the sediments suspended in $600 \mu \mathrm{L}$ of TE following new centrifugation in the same conditions. The sediment was then suspended in $600 \mu \mathrm{L}$ of lisis buffer (Tris- $\mathrm{HCl} 100 \mathrm{mM}$, EDTA 0,125 mM, SDS 1,0\%, 2-mercaptoetanol 0,2\% and water Milli-Q q.s.p.) and incubated at $56^{\circ} \mathrm{C}$ for 1 h. After this period samples were incubated in water bath at $95^{\circ} \mathrm{C} /$ $10 \mathrm{~min}$. Soon after, $20 \mu \mathrm{L}$ of Proteinase-K $(20 \mathrm{mg} / \mathrm{mL})$ were added to each microtube, which was incubated at $56^{\circ} \mathrm{C}$ overnight. Afterwards, $500 \mu \mathrm{L}$ of phenol, chloroform, and isoamilic alcohol mixture were added (25:24:1) to tubes, they were homogenized and centrifuged at $25^{\circ} \mathrm{C} / 13.000 \mathrm{rpm} / 20 \mathrm{~min}$. The supernatants were carefully collected and transferred into new micro tubes, and the phenol/chloroform/isoamilic alcohol extraction was repeated once more. DNA was precipitated with isopropanol and $10 \mu \mathrm{L}$ of sodium acetate $3 \mathrm{M}$, at $-20^{\circ} \mathrm{C}$ for 30 minutes. The material obtained was centrifuged at $4^{\circ} \mathrm{C} / 13.000 \mathrm{rpm} / 20 \mathrm{~min}$ and the "pellet" washed twice with ethanol $70 \%$. After drying at $37^{\circ} \mathrm{C}$ for $1 \mathrm{~h}, \mathrm{DNA}$ was eluted in $100 \mu \mathrm{L}$ of sterile Milli-Q water. DNA visualization and quantification were done in $1 \%$ agarose gel (Sigma, Oakland, USES) stained with ethidium bromide $(10 \mu \mathrm{g} / \mathrm{mL})$. Low Mass molecular weight marker was used (Invitrogen).

PCR amplification. For the amplification of the $M$. leprae specific repetitive sequence, a set of primers $5^{\prime}$ GCACGTAAGCCTGTCGGTGG-3' and 5'-CGGCCGGATCCTCGATGCAC-3' were used. ${ }^{6,25}$ PCR amplifications were performed in a Thermal Cycler PTC-100TM - 480 model (Peltier-Effect Cycling MJ Research, USA). DNA (10 ng) was mixed with $200 \mathrm{mM}$ of each deoxynucleotide triphosphate, $10 \mathrm{mM}$ of each primer, $50 \mathrm{mM} \mathrm{KCl}, 1,5 \mathrm{mM}$ $\mathrm{MgCl} 2,10 \mathrm{mM}$ Tris- $\mathrm{HCl}$ (pH 9,0), $1 \mathrm{U}$ of Taq polymerase (GE Healthcare) and water to a final volume of $25 \mathrm{~mL}$. Cycling consisted of $92^{\circ} \mathrm{C}$ for $3 \mathrm{~min}$, followed by 40 cycles of $2.5 \mathrm{~min}$ at $55^{\circ} \mathrm{C}, 2 \mathrm{~min}$ at $72^{\circ} \mathrm{C}$ and $1.5 \mathrm{~min}$ at $92^{\circ} \mathrm{C}$, and a final extension cycle at $72^{\circ} \mathrm{C}$ for $7 \mathrm{~min} . .^{7}$ Samples were analyzed in a $1.5 \%$ agarose gel (Sigma, Oakland, USA) stained with ethidium bromide $(10 \mathrm{mg} / \mathrm{mL})$.

Sequencing of PCR fragments. The amplified products were purified using the kit GFX (GE Healthcare). Sequencing was performed in the Center of Genomic Studies (Institute of Biosciences, University of São Paulo (USP), SP, Brazil), using the MegaBACE 1000 Sequencer (GE Healthcare). Reactions were run according to the manufacturers' protocol. Once logged, sequences obtained were aligned and edited using the software "Chromas" and "Sequence Navigator" (Perking Elmer) and analyzed in the Gene Bank: Blast-n program (http://www.ncbi.nlm.nih.gov/BLAST/Blast.cgi). 


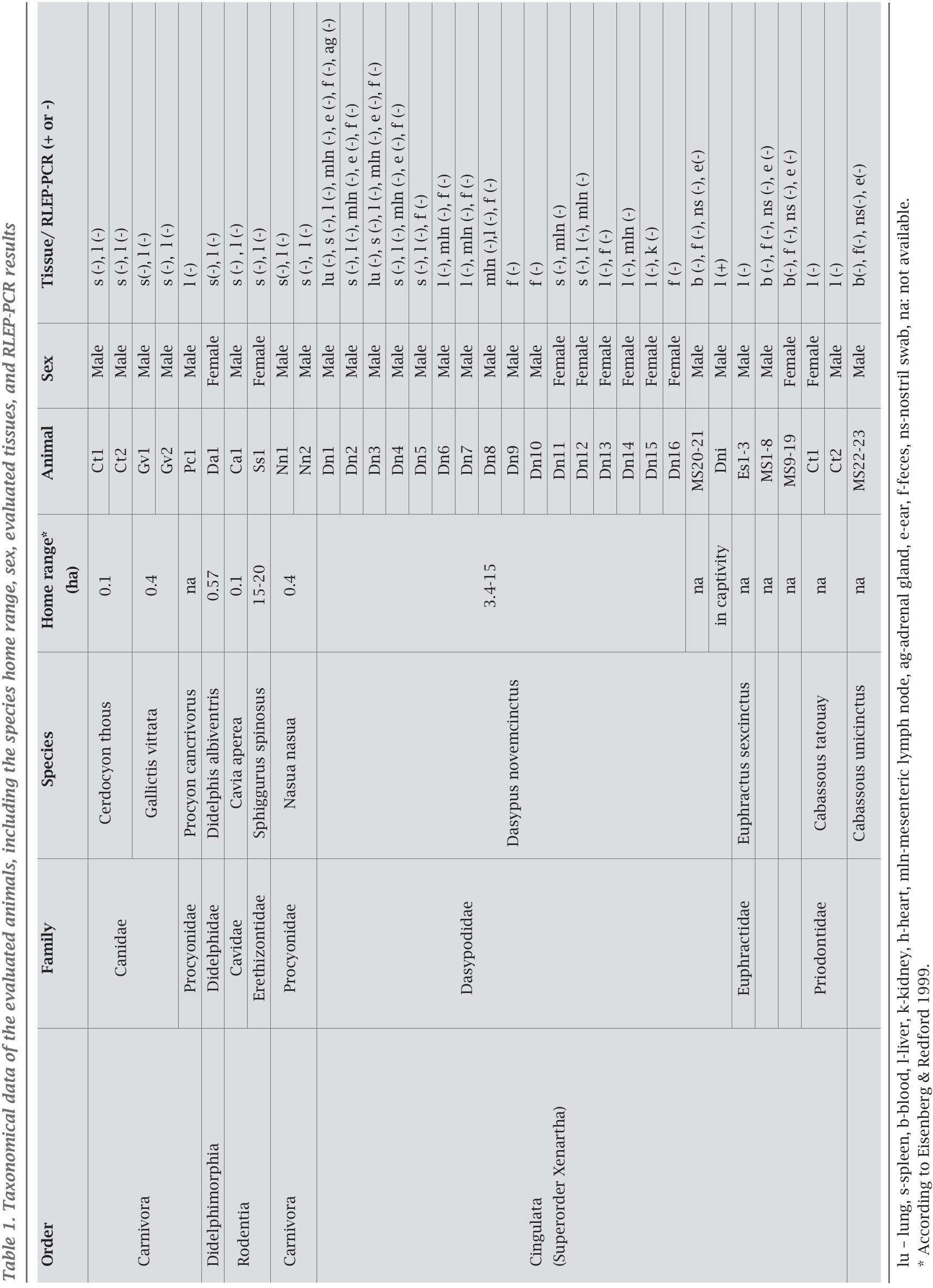




\section{RESULTS}

There was not growth of Mycobacteria in samples incubated at $37^{\circ} \mathrm{C}$. No mycobacteria were visualized in the organ samples submitted to histopathological examination and bacilloscopy.

The PCR reactions were negative for M. leprae in all wild mammals (Table 1). ${ }^{26,27}$ Only the liver sample of the experimentally inoculated $D$. novemcinctus was PCR positive for the RLEP region specific for M. leprae. A 372bp fragment could be visualized in the agarose gel. (Figure 1). The genomic sequencing of the amplified product revealed $100 \%$ of homology with M. leprae.

Figure 1: Specific repetitive element of $M$. leprae (RLEP), demonstrated by visualization of a $372 \mathrm{bp}$ product. $1-\mathrm{M}$. smegmatis MC2 155; 2 - M. avium; 3 - Hamster M. auratus inoculated with M. avium (liver DNA); 4, 5, and 6 - D. novemcinctus inoculated with $M$. leprae (liver); 7 - Negative control of reaction; 8 - Low Mass DNA ladder.

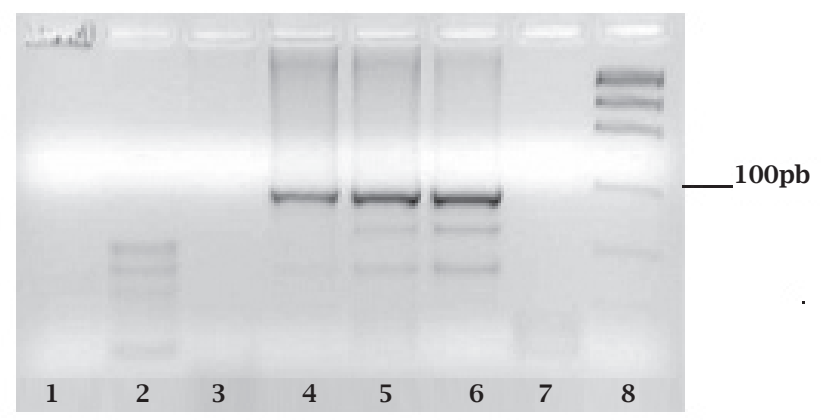

\section{DISCUSSION}

Genomic comparative studies show that $M$. leprae presents signatures characteristic of an extremely specialized and highly host dependent pathogen. The comparative analysis of the M. tuberculosis genome (complete genome with $4.411 .532 \mathrm{bp}$ ) with $M$. leprae genome (complete genome with $3.268 .203 \mathrm{bp}$ ) reveals that only $49,5 \%$ of the $M$. leprae genome contain genes that codify proteins and $27 \%$ of then represent "pseudo genes", in other words, genes that were turned off in M. leprae but are still functional in M. tuberculosis. ${ }^{28}$

Similarly to leprosy, the Buruli ulcer caused by Mycobacterium ulcerans is a serious skin disease in humans and its incidence overcomes that of leprosy in countries, such as Australia and Papua New Guinea. ${ }^{29}$ The M. ulcerans genome resembles the $M$. leprae genome, showing significant loss of genetic redundancy and of metabolic pathways. ${ }^{30}$ Through comparative analysis of genomic sequences, it was discovered that $M$. ulcerans emerged from M. marinum by the acquisition of genes responsible for mycolactone- $\mathrm{A}$ production, an immunosuppressive cytotoxin that provokes a serious necrotic ulceration in the subcutaneous tissue. The evolutionary reduction and the genomic rearrangement remodeled $M$. marinum, a fish and toads pathogen, into M. ulcerans. This organism is apparently adapted now to a dark and aerobic atmosphere, where its reduced antigenicity, slow growth, and mycolactone production provided advantages for its survival. ${ }^{29}$

This process of genomic reduction is also documented in other obligate intracellular parasites, such as Rickettsia and Chlamydia spp. in witch some genes became inactivated, once their functions are no longer necessary in highly specialized niches. Also Yersinia pestis apparently diverged recently from Y. pseudotuberculosis to engage the midgut of fleas, whereas Bordetella pertussis derived from B. bronchiseptica to become an obligatory human pathogen..$^{30}$

M. leprae may have followed this same evolutionary trend, with a minimum amount of active genes needed for its adaptation to the host, without, losing their characteristic pathogenicity. This process of evolutionary reduction indicates that the microorganism tried rearrangements and deletions of its genome and suffered an evolutionary adaptation process extremely well established in human host.

In this way, the Hansen's bacillus has been cohabitating with man for more than 2,600 years, and it remains, still today, in the second decade of the 21st century, as an extremely preoccupying pathogen in tropical climate countries, like Brazil, India, Madagascar, and African countries, with high detection rates (more than 690,000 new cases of the disease registered annually in the world). Only, after the 1980s, with the success of multidrug therapy, transmission rates were reduced.

Despite reports of the existence of natural disease in some primates species in Africa (mangabeys monkeys, Cynomolgus, chimpanzees, ${ }^{9}$ and in armadillos D. novemcinctus in certain geographical areas of the United States (Texas and Louisiana), ${ }^{17,18}$ few studies were carried out in Brazil. We didn't find any natural infection in the studied wild mammals in the Middle Western region of São Paulo state; neither in Mato Grosso do Sul Pantanal. Although other wild species have never been implicated with $M$. leprae infection, excluding armadillos and some non-human primates, other species of armadillos and Brazilian road killed mammals had never been researched for this purpose. Deps et al. (2002) found that blood samples of 5 out of 14 animals were positive for M. leprae by PCR. ${ }^{31}$ In another study, Deps et al. (2007) found 11 out of 37 (29.7\%) positive serum samples using the ML Flow test. ${ }^{32}$

Search for M. leprae in wild armadillos D. novemcinctus of different geographical areas resulted negative in Florida, Colombia, Paraguay, ${ }^{33-35}$ and in the Southeast area of the United States, corresponding to Alabama, Ar- 
kansas, Florida, Georgia and Mississipi, besides other 800 armadillos examined in Florida. ${ }^{33,36}$

In the biodiversity of Latin America fauna, of the actual 20 known armadillo's species, 17 are only found in Brazil and have been little studied. It has been shown that these animals can be natural carriers of important pathogens such as Trypanosoma cruzi, ${ }^{37,38}$ Histoplasma capsulatum, ${ }^{39}$ Leishmania naiffi, ${ }^{40}$ Toxoplasma gondii, ${ }^{41}$ and Paracoccidioides brasiliensis. ${ }^{42-44}$

The nine-banded armadillos, family Dasypodidae, order Cingulata, Superorder Xenarthra, ${ }^{13}$ were introduced in North America very recently, around the year 1880. The human civilization, that probably appeared in Africa 400,000200,000 years ago, arrived in America much later, being South America the last part of the continent to be colonized by man about 14,000 years ago..$^{4,45}$

The discovery of armadillos from Louisiana naturally infected with M.leprae, SNP type 3 strain, originating from Europe and North of Africa, is an indicative that those animals were contaminated by human sources. ${ }^{19}$ The M. leprae bacillus was probably carried to the New World about 500 years ago, after the arrival of settlers and through the African slave's traffic. As several species of armadillos already lived in Latin America from the Paleocene era, when leprosy did not exist in humans, it is possible to infer that if there are $D$. novemcinctus naturally infected in certain areas of the United States; these animals must have been infected by man and not the contrary. Prabhakaran, in 1998, already questioned if armadillos were, besides man, reservoirs of $M$. leprae, once the disease was brought from the Old to the New World where native inhabitants and armadillos lived without leprosy. ${ }^{46}$

Experimentally, not all the animals are susceptible to the infection by $M$. leprae, because some do not develop the disease (20-30\%), even when inoculated with high bacillary loads. However, it is admitted that the armadillos may show an immune status similar to that of some patients with tuberculosis, in which the disease is auto-limited. ${ }^{12,20,21}$ In that case, however, armadillos would remain for some time with high IgM antibody titles against PGL-1 antigen. The study of Deps et al.(2007), using ML-flow, may reflect this situation. ${ }^{32}$

The objective of the present study was to identify indigenous leprosy in wild animals, looking for a better understanding of transmission. Some questions are yet to be answered: are armadillos and other animals of South America indeed naturally infected by the M. leprae? Would they be involved in the epidemic chain of the disease? Were armadillos infected by human bacilli from Texas and Louisiana or did man, once again, interfere in the environment thus contaminating armadillos that were living in those regions?

Our study suggests that the armadillos of the São Paulo and Mato Grosso do Sul states were not contaminated by man, because, despite the small sampling, no naturally infected animals were found. The results obtained showed that M. leprae is fundamentally an anthropophilic pathogen, and in that respect wild animals should play a small or null role as natural reservoirs.

\section{ACKNOWLEDGEMENTS}

Financial support: this work was supported by Fundação Paulista Contra a Hanseníase.

\section{REFERENCES}

1. Browne SG. In: Hastings RC (ed), Leprosy. Churchill Livingstone, Edinburgh, 394-5, 1994.

2. Noordeen SK. The epidemiology. In: Hastings, Robert C. (Ed.) Leprosy. 2.ed. Edinburgh: Churchill Livingstone: 2934. 1994.

3. Williams DL, Gillis TP, Fiallo P et al. Detection of Mycobacterium leprae and the potential for monitoring antileprosy drug therapy directly from skin biopsies by PCR. Molec and Cell Probes 1992; 6: 401-10.

4. Telenti A, Marchesi F, Balz M, Bally F, Böttger EC, Bodmer T. Rapid Identification of Mycobacteria to the species level by Polymerase Chain Reaction and restriction enzyme analysis. J Clin Microbiol 1993; 31: 175-8.

5. Rastogi N, Goh KS, Berchel M. Species-specific identification of Mycobacterium leprae by PCR-Restriction Fragment Length Polymorphism Analysis of the hsp65 gene. J Clin Microbiol 1999; 37: 2016-9.

6. Woods SA, Cole ST. A rapid method for the detection of potentially viable Mycobacterium leprae in human biopsies: a novel application of PCR. FEMS Microbiol Lett 1989; 65: 305-10.

7. Santos AR, De Miranda AB, Sano EN, Suffys PN, Degrave WM. Use of PCR-mediated amplification of Mycobacterium leprae DNA in different types of clinical samples for the diagnosis of leprosy. J Med Microbiol 1993; 39: 298-304.

8. Meyers WM, Gormus BJ, Walsh GP, Baskim GB, Hubbard GB. Naturally-acquired and experimental leprosy in nonhuman primates. Am J Trop Med and Hyg 1991; 44: 24-7.

9. Rojas-Espinosa O, Lovik M. Mycobacterium leprae and Mycobacterium lepramurium infections in domestic and wild animals. Rev Sci Tech Off Int Epiz 2001; 20: 219-51.

10. Storrs EE. The nine-banded armadillo: a model for leprosy and other biomedical research. Int J Lepr Other Mycobact Dis 1971; 39:703-714.

11. Kirchheimer WF, Storrs EE. Atttempts to establish the armadillo (Dasypus novemcinctus linn.) as a model for the study of leprosy. Report of lepromatous leprosy in an experimentally infected armadillo. Int J Lepr Other Mycobact Dis 1971; 39:692.

12. Rosa PS, Belone AFF, Silva EA. Mitsuda reaction in armadillos Dasypus novemcinctus using human and armadillo derived antigens. Hansen Int 2005a; 30:174-9.

13. Gardner AL. Order Cingulata. v. 1:94-9. In: Wilson D.E. \& Reeder D.M. eds. Mammal Species of the World, 3rd edition. Baltimore, MD: John Hopkins University Press, 2 Volumes, p.2141. 2005 . 
14. Laguna AF. El cachicamo sabanero: aspectos de su biologia y ecologia. Fondo Edit Acta Cient Venezol 15-7; 1984.

15. Nowak RM. Walker's Mammals of the World. 6th Ed. Johns Hopkins University Press, Baltimore, 515-535. 1999.

16. Wetzel RM. The identification and distribution of recent xenarthra (Edentata) and taxonomy and distribuiton of armadillo, Dasypodidae. In: Montgomery, GG. (Ed), The Evolution and Ecology of Armadillos, Sloths and Vermilingua. Smithsonian Institution, Washington, 279-92. 1985.

17. Meyers WM, Walsh GP, Brown HL, Rees RJW, Convit J. Naturally acquired leprosy-like disease in the nine-banded armadillo (Dasypus novemcinctus): Reactions in leprosy patients to lepromins prepared from naturally infected armadillos. J Reticuloendothel Soc 1977; 22:369.

18. Truman RW, Job CK, Hastings RC. Antibodies to the phenolic glycolipid-1 antigen for epidemiologic investigations of enzootic leprosy in armadillo (Dasypus novemcinctus). Lepr Rev 1990; 61:19-24.

19. Monot M, Honoré N, Garnier T et al. On the Origin of Leprosy. Science 2005; 308: 1040-1042.

20. Rosa PS, Belone AFF, Silva EA, Pedrini SCB, Pinke CAE. Inoculação experimental de tatus com o M. leprae: resultados preliminares. 10ọ Congresso Brasileiro de Hansenologia, Recife, Brasil. 2005b; 19-22.

21. Rosa PS, Silva EA, Pedrini SCB, Pinke CAE. The Effect of Iron Supplementation in the Diet of Dasypus novemcinctus Armadillos in Captivity. Braz J Biol 2009; 69:1 (in press).

22. Brasil, Ministério da Saúde - FNS/CENEPI/CNPS/CRPHF. 1994. Manual de bacteriologia da tuberculose. 20ạ ed.

23. Leal NC, Almeida AMP. Diagnosis of plague and identification of virulence markers in Yersinia pestis by multiplex-PCR. Rev Inst Med Trop de São Paulo 1999; 41:339-42.

24. Mahbubani MH, Bej AK. Applications of polimerase chain reaction methodology in clinical diagnostics. In: Griffin, L.C., Griffin, A.M. (Eds). PCR Technology: Current innovations. Boca Raton: 307-326. 1994.

25. Grosskinsky CM, Jacobs Jr WR, Clark-Curtiss JE, Bloom BR. Genetic Relationships among Mycobacterium leprae, Mycobacterium tuberculosis, and Candidate leprosy Vaccine Strains Determined by DNA Hybridization: Identification of an M. leprae-Specific Repetitive Sequence. Infect Immun 1989; 57:1535-41.

26. Eisenberg Jf, Redford K. eds. Mammals of the Neotropics. The University of Chicago Press, Chicago and London, 1999.

27. Medri, IM. Ecologia e História Natural do Tatu-peba, Euphractus sexcinctus (Linnaeus, 1758), no Pantanal da Nhecolândia, Mato Grosso do Sul. (Thesis) University of Brasília, 2008.

28. Cole S.T., Eigimeier K., Parkhii J. et al. Massive gene decay in the leprosy bacillus. Nature 2001; 409:1007-11.

29. Stinear T, Johnson DR. From Marinum to Ulcerans: a $m y$ cobacterial human pathogen emerges. Microbe 2007; 2:18794.

30. Stinear TP, Seemann T, Pidot S et al. Reductive evolution and niche adaptation inferred from the genome of Mycobacterium ulcerans, the causative agent of Burulli ulcer. Gen Res 2007; 17:192-200.
31. Deps PD, Santos AR, Yamashita-Tomimori J. Detection of Mycobacterium leprae DNA by PCR in blood sample from nine-banded armadillo: Preliminary results. Int J Lepr other mycobact Dis 2002: 70:34-5.

32. Deps PD, Antunes JMAP, Tomimori-Yamashita J. Detection of Mycobacterium leprae infection in wild nine-banded armadillos (Dasypus novemcinctus) using the rapid ML Flow test. Rev Soc Bras Med Trop 2007; 40:86-7.

33. Kirchheimer WF, Sanches RM. Examination of North American armadillos for mycobacteriosis. Lepr India 1978; 50:15660 .

34. Kirchheimer WF. Examination of north american armadillos for mycobacteriosis - a further report. Lepr India 1979; 51:60-6.

35. Howerth EW, Stallknecht DE, Davidson WR, Wentworth EJ. Survey for leprosy in nine-banded armadillos (Dasypus novemcinctus) from the Southeastern United States. J Wildlife Dis 1990; 26: 112-5.

36. Walsh GP, Storrs EE, Meyers WM, Binford CH. Naturally acquired leprosy-like disease in the nine-banded armadillo (Dasypus novemcinctus): recent epizootiologic findings. J Reticuloendothel Soc 1977; 22:363-7.

37. Barreto MP. Reservatórios e vetores de Trypanosoma cruzi no Brasil. Arq Hig Saúde Pub. 1963; 28: 43-66.

38. Lainson R, Shaw JJ, Fraha H, Miles MA, Draper CC. Chagas's disease in the Amazon basin: I. Trypanossoma cruzi infections in silvatic mammals, triatomine gugs and man in state of Pará, north Brazil. Trans Royal Trop Med Hyg 1979; 73: 193-204.

39. Arias JR, Naiff RD, Naiff MF, Mok WY, Almeida MMR. Isolation of Histoplasma capsulatum from an armadillo (Dasypus novemcinctus) in the eastern Amazon of Brazil. Trans Royal Soc Trop Med Hyg 1982; 76:705-6.

40. Naiff RD, Freitas RA, Naiff MF et al. Epidemiological and nosological aspects of Leishmania naiffi. Mem Inst Oswaldo Cruz 1991; 86:317-21.

41. Sogorb F, Jamira LF, Guimarães EC. Toxoplasmose em animais de São Paulo, Brasil. Rev Inst Med Trop São Paulo 1977; 19:91-4.

42. Naiff RD, Ferreira LCP, Barrete TV, Naiff MF, Arias JR. Paracoccidioidomicose enzoótica em tatus (Dasypus novemcinctus) no estado do Pará. Rev Inst Med Trop São Paulo 1986; 53:19-27.

43. Bagagli E, Sano A, Coelho KIL et al. Isolation of Paracoccidioides brasiliensis from armadillos (Dasypus novemcinctus) captured in an endemic area of paracoccidioidomycosis. Am J Trop Med Hyg 1998; 58:505-12.

44. Bagagli E, Bosco SMG, Theodoro RC, Franco M. Phylogenetic and evolutionary aspects of Paracoccidioides brasiliensis reveal a long coexistence with animal hosts that explain several biological features of the pathogen. Infect Genet and Evol 2006; 6: 344-51.

45. Leakey RE. Human Origins. Lodestar Books, New York: 87. 1982.

46. Prabhakaran K. Why Mycobacterium leprae invades the eyes? Indian J Lepr 1998; 70:413. 